\title{
Heat Treatment of Whole Milk by the Direct Joule Effect-Experimental and Numerical Approaches to Fouling Mechanisms
}

\author{
L. Fillaudeau, ${ }^{* 1}$ P. Winterton, ${ }^{\star}$ J. C. Leuliet, $\dagger$ J. P. Tissier, $\dagger$ V. Maury, $\dagger$ F. Semet,$\dagger$ \\ P. Debreyne, $†$ M. Berthou, $\ddagger$ and F. Chopard§ \\ *Institut National des Sciences Appliquées (INSA), Laboratoire de Biotechnologie-Bioprocédés, Centre National de la Recherche Scientifique \\ (CNRS) Unité Mixte de Recherche (UMR) 5504, Institut National de la Recherche Agronomique (INRA) UMR 792-135, avenue de \\ Rangueil, F-31077 Toulouse Cedex 4, France \\ tINRA-Laboratoire de Génie des Procédés et Technologie Alimentaires (LGPTA) 369, rue Jules Guesde, 59650 Villeneuve D’Ascq Cedex, \\ France \\ łEDF-R\&D, Les Renardières, 77818 Moret Sur Loing Cedex, France \\ §Alfa-Laval Vicarb, rue du Rif Tronchard, 38120 Fontanil-Cornillon, France
}

\begin{abstract}
The development of alternative technologies such as the direct Joule effect to pasteurize and sterilize food products is of great scientific and industrial interest. Our objective was 1) to gain insight into the ability to ensure ultra-high-temperature treatment of milk and 2) to investigate the links among thermal, hydraulic, and electrical phenomena in relation to fouling in a direct Joule effect heater. The ohmic heater $[\mathrm{OH}$; $\vec{E} \perp \vec{v}$ (where $E$ is the electrical field and $v$ is the velocity); $P$ (power) $=15 \mathrm{~kW}$ ] was composed of 5 flat rectangular cells $[e$ (space between the plate and electrode $)=15$ $\mathrm{mm}, w$ (wall) $=76 \mathrm{~mm}$, and $L$ (length of the plate in plate heat exchanger or electrode $)=246 \mathrm{~mm}]-3$ active cells to ensure heating and 2 (at the extremities) for electrical insulation and the recovery of leakage currents. In the first step, the thermal performance of the $\mathrm{OH}$ was investigated vs. the flow regimen $[50<R e$ (Reynolds number $)<5,000]$, supplied power $(0<P<$ $15 \mathrm{~kW})$, and electrical conductivity of fluids $\left(0.1<\sigma_{20}{ }^{\circ} \mathrm{C}\right.$ $<2 \mathrm{~S} / \mathrm{m}$ ) under clean conditions with model fluids. This protocol enabled a global thermal approach (thermal and electrical balance, modeling of the temperature profile of a fluid) and local analysis of the wall temperature of the electrode. An empirical correlation was established to estimate the temperature gradient, $T_{w}-T_{b}$ (where $T_{w}$ is the wall temperature and $T_{b}$ is the product temperature) under clean conditions (without fouling) and was used to define operating conditions for purevolume and direct-resistance heating. In the second step, the ability of $\mathrm{OH}$ to ensure the ultra-high-temperature treatment of whole milk was investigated and compared with a plate heat exchanger. Special care was taken to investigate the heat transfer phenomena
\end{abstract}

Received February 23, 2006.

Accepted June 14, 2006.

${ }^{1}$ Corresponding author: Luc.Fillaudeau@insa-toulouse.fr occurring over a range of temperatures from 105 to $138^{\circ} \mathrm{C}$. This temperature range corresponds to the part of the process made critical by protein and mineral fouling. The objectives were 1) to demonstrate the ability of an $\mathrm{OH}$ to ensure heat treatment of milk, 2) to study the thermal and hydraulic performance with an increasing power and temperature difference between the inlet and outlet of the $\mathrm{OH}, 3$ ) to define and validate a criterion to follow heat dissipation efficiency, and 4) to compare the fouling propensity with the different configurations. A heat dissipation coefficient, $R h_{\mathrm{CO}}$, was defined and validated to monitor the fouling propensity through global electrical and thermal parameters. Finally, a numerical simulation was developed to analyze heat profiles (wall, deposit, bulk). Because of an increasing Joule effect in the static deposit, the simulation showed how wall overheating would definitively cause fouling to spiral out of control.

Key words: ohmic heating, wall overheating, fouling, whole milk

\section{INTRODUCTION}

Heat treatment remains the oldest and the most frequently used preservation process in the food industry (heating, pasteurization, sterilization, cooking, and cooling). To perform these operations, heat exchangers are still fundamental pieces of equipment throughout the food processing industry. In spite of great improvements in conventional technologies over the last few decades, the heat treatment of dairy products remains a complex operation. First, fouling occurs during heat treatment and reduces the performance as well as the duration of the production cycle. Second, industrial and legal requirements in terms of sterilization level involve higher temperatures to eliminate all heat-resistant germs. In this context, any new technologies used to pasteurize or sterilize food by thermal treatment [geometrical modification, Joule effect heating, ohmic heat- 
ing $(\mathbf{O H})]$ in a continuous process or by nonthermal treatment (crossflow filtration, high-pressure process, high-intensity light emission, radiation, cell lysis) are of great scientific and industrial interest.

Ohmic heating is based on a simple mechanism-the generation of heat directly inside the product by the Joule effect. It consists of causing an electrical current to flow directly through the medium to be treated, flowing between a pair of electrodes. This technique can be applied to liquids containing free ions, which are therefore electrical conductors. Constant movement of electrical charges creates heat in the product according to Joule's law. Heat generation is a direct function of geometry, the electrical conductivity of a given product, and voltage (Aussudre et al., 1998; Ould-El-Moctar, 1992). Ohmic heating is defined as pure-volume and direct-resistance heating, as opposed to heating by convection from the hot surface of a heat exchanger. Consequently, the heat transfer coefficient between the hot wall and the fluid is assumed to be irrelevant because there is theoretically no hot wall. From a fundamental point of view, direct-resistance heating of liquids is a complex physical problem in which strong interactions between heat transfer, hydrodynamics, and electrical phenomena can be observed (De Alwis and Fryer, 1990; Ould-El-Moctar et al., 1993). The nonexistence of a hot wall should constitute a major advantage for food applications, thereby avoiding degradation of heat-sensitive compounds (causing changes in taste, undesirable reactions, or burning) and reducing the fouling of electrode surfaces (Fillaudeau et al., 2001; Ayadi, 2005). Other advantages are related to the use of electricity because energy conversion (electrical into heat energy) is close to $100 \%$ and the uniformity of heating is greatly improved. This technology involves a short thermal inertia and fast, simple, and precise regulation is possible. Heat transfer is a function of the electrical and thermal parameters.

Ohmic heating is a technology that appeared in the 19 th century when electrical energy was used for heating materials with a capacity to flow (Bhat and Joshi, 1998). A limited number of scientific articles dealing with the $\mathrm{OH}$ of milk have been published, mainly at the beginning of the last century (Anderson and Finkelstein, 1919; Getchell, 1935; Prescott, 1927). Unfortunately, this technology did not succeed because of the lack of suitable electrode materials and accurate, automatic electrical controls. During the past $10 \mathrm{yr}$, new and improved materials and designs for $\mathrm{OH}$ have become available (Aussudre et al., 1998; Berthou and Aussudre, 2000). However, the main scientific works and industrial practices are dedicated to the sterilization of lowacid food products containing particles in continuous (Biss et al., 1989; Yang et al., 1997; Eliot-Godereaux et al., 2001) and discontinuous processes (Sastry and Palaniappan, 1992; Zareifard et al., 2003). More recently, some scientific works have investigated the $\mathrm{OH}$ of homogeneous liquids in continuous processes (OuldEl-Moctar, 1992; El-Hajal, 1997; Fillaudeau, 2004; Ayadi, 2005) but have rarely investigated the heat treatment (pasteurization, sterilization) of real products (Fillaudeau et al., 2001).

The present work aims to understand the interactions occurring among hydraulic, thermal, and electrical phenomena in relation to fouling in a continuous ohmic apparatus [3 rectangular cells, $e=15 \mathrm{~mm}, w=$ $76 \mathrm{~mm}$, and $L=246 \mathrm{~mm}$, where $e$ is the space between the plate or electrode, $w$ is the wall, and $L$ is the length of the plate in a plate heat exchanger (PHE) or electrode; $\vec{E} \perp \vec{v}$, where $E$ is the electrical field and $v$ is the velocity] and to gain insight into the ability to ensure the UHT treatment of whole milk. In the first step, overheating of the electrode surface was investigated with 2 model fluids under clean conditions (without fouling) to analyze and model the temperature gradient between the wall (electrode) and fluid vs. the operating conditions. In the second step, the impact of fouling on thermal and electrical parameters was studied during the sterilization of whole milk. Deposition was compared, as observed with a PHE. A heat dissipation coefficient, $R h_{\mathrm{CO}}$, based on global electrical and thermal parameters, was defined and validated to monitor fouling. Finally, a numerical simulation was developed to analyze thermal profiles (wall, deposit, fluid) along the ohmic heater. Because of an increasing Joule effect in the static deposit, wall overheating can cause fouling to spiral out of control.

\section{MATERIALS AND METHODS}

\section{Experimental Setup}

The experimental setup consisted of 3 different sections: 1) a preheating zone (heater I), 2) a heating zone with a PHE or ohmic heater (heater II), and 3) a cooling zone. It included the following elements in series: 2 storage tanks $\left(2.5 \mathrm{~m}^{3}\right)$, a constant level tank, a volumetric feed pump (type K320SD; Inoxpa, Banyoles, Spain; $Q_{\max }=800 \mathrm{~L} / \mathrm{h}$, where $Q$ is the volume flow rate), a preheater (heater I), a heater (heater II), a tubular heat exchanger as cooler, and a manual valve at the installation outlet.

The ohmic heater was composed of 5 rectangular cells in series $(e=15 \mathrm{~mm}, w=76 \mathrm{~mm}$, and $L=246 \mathrm{~mm}): 3$ cells $(1,2$, and 3 ) that ensured heating and 2 (at the extremities) for electrical insulation and the recovery of leakage currents (Fillaudeau et al., 2004; Ayadi, 2005). Electrodes and gaskets were placed between cells to maintain waterproofing and to enable the flow of the 
product, and $180^{\circ}$ junctions ensured a hydraulic connection between cells. The geometry of the ohmic cells imposed an electrical field perpendicular to the flow pattern, $\vec{E} \perp \vec{v}$. Temperature regulation at the ohmic heater outlet was carried out by controlling the electrical power (15-kW generator, 3-phase system, triangular connection). The power was controlled by a phase angle (voltage and current regulation, $\mathrm{AC}$ current, $50 \mathrm{~Hz}$ ) up to the maximum acceptable voltage and intensity $\left(U_{\max }=100 \mathrm{~V}, I_{\max }=170 \mathrm{~A}\right.$, where $U$ is the electrical potential and $I$ is the current). Electrolytic reactions may occur at the electrode-solution interface if continuous or alternating currents flow through an electrolyte. Electrolytic reactions can be prevented if the potential drop at the electrode-solution interface can be kept below the critical electrode potential, which depends on the physical and chemical properties of the electrode, $\mathrm{pH}$ values, current frequency, and density (Amatore et al., 1998; Sastry, 2003; Samaranayake and Sastry, 2005). In our working conditions, electrolysis is unlikely because of the current frequency $(50 \mathrm{~Hz})$ and density $\left(<5,000 \mathrm{~A} / \mathrm{m}^{2}\right)$ used with a specific electrode material named a dimension-stable anode. Dimension-stable anode electrodes have been patented (Berthou et al., 1998) and are made out of titanium with a layer of noble metal oxides ( $\mathrm{Ru}, \mathrm{Ir}, \mathrm{Ta}$, etc.).

With fouling fluids (whole milk), experiments were carried out on 2 experimental setups (Fillaudeau et al., 2001). The first experimental device, used for configuration 1, consisted of a PHE only (V7 type; Vicarb France, Fontanil-Cornillon, France) equipped with straight corrugation plates (corrugations perpendicular to the main flow direction). The second experimental pilot plant (Experiments 2 to 5) consisted of an association between a PHE (V2 type; Vicarb France) equipped with a $60^{\circ}$ corrugation angle and an ohmic heater. The design of the pilot plant enabled heat treatment to be carried out with a high degree of autonomy (electrical power control, temperature regulation, and fluid flow). In the PHE, a countercurrent fluid flow was created, and the nitril gaskets allowed operating conditions of up to $1 \mathrm{MPa}$ and $140^{\circ} \mathrm{C}$. In configurations 2 to 5 , heat power was entirely supplied by the ohmic heater.

\section{Measurement of Process Parameters}

Specific instrumentation enabled the measurement of flow rate, temperature, electrical conductivity, voltage, intensity, differential pressure, and relative pressure. All flow rates were measured using an electromagnetic flow meter (type DN25; Khrone, Duisberg, Germany) accurate to within $1 \%$ of the full range. Temperatures were measured by means of platinum resistance probes (\#2327; type Pt 100 $\Omega$, precision $\pm 0.2^{\circ} \mathrm{C}$; Sensor-Nite, Kleinostheim, Germany) placed at the inlet and outlet of each zone. Relative pressure sensors (manometer, type 4AP30, precision $0.1 \%$; JUMO, Fulda, Germany) were placed at the inlet and outlet of the experimental setup, whereas 2 differential pressure sensors $(0$ to $25 \mathrm{kPa}$ and 0 to $200 \mathrm{kPa}$; Schlumberger, La Defense, France) were used on heaters I and II to monitor the exacerbation of a pressure drop when fouling occurs. In addition, the electrical conductivity (conductimeter, type 9111 , accurary $0.1 \%$; Keotron, Lyngby, Denmark) was measured at the inlet of the loop and at the outlet of the ohmic heater.

Electrode wall temperatures were measured along the ohmic heater by 12 thermocouples (ThC; sensor, type $\mathrm{J}$ electrically insulated ThC, \#J05X, accuracy $\pm 0.5^{\circ} \mathrm{C}$, ThC- 0 to ThC-12; Corame, C2M, Mont St-Aignan, France) with nonfouling model fluids (Figure 1). Electrical power was determined from the voltage measured between the second and third electrodes (voltmeter, 0 to 250 V, Sineax U504; Chauvin Arnoux, Paris, France) and the intensity on phase 2 of the electrical transformer (ammeter, 0 to $200 \mathrm{~A}$, type AC22; Camille Bauer, Wohlen, Switzerland). All signals were electrically conditioned (module SCX-1) and collected using a data acquisition card (AT-MOI-16E-10; Agilent Technologies, Palo Alto, CA). A NI-DAQ (National Instruments-Data Acquisition; National Instruments, Austin, TX) software driver enabled configuration and control of the data acquisition system. Measurements were saved on a PC (Pentium, $200 \mathrm{MHz}$ ) with LabVIEW software (National Instruments).

\section{Properties of Fluids and Operating Conditions}

With Nonfouling Fluids (Water, Sucrose Solution). Model fluids were, respectively, 1) water and 2) a sucrose solution $(50 \%, \mathrm{wt} / \mathrm{wt})$. Their physical properties ( $\rho, C, \lambda, \mu$, where $\rho$ is the volume mass, $C$ is the specific heat capacity, $\lambda$ is the thermal conductivity, and $\mu$ is the viscosity) were measured and compared with the literature (Norrish, 1967; Weast, 1983-1984). Electrical conductivities $(\sigma)$ were adjusted by sodium chloride adjunction (3 conductivities per solution) and described vs. temperature (Table 1). Electrical conductivity of the solutions was included within the range of values of liquid food products (Fillaudeau, 2004).

Thermal performance of the ohmic heater was investigated vs. the flow regimen $(50<R e<5,000$, where $R e$ is the Reynolds number), the power supplied $(0<P<$ $15 \mathrm{~kW})$, and the electrical conductivity of fluids $(0.1<$ $\left.\sigma_{20{ }^{\circ} \mathrm{C}}<2 \mathrm{~S} / \mathrm{m}\right)$. This protocol enabled a global thermal approach (thermal and electrical balance, modeling of the temperature profile of the fluid) and a local analysis of the wall temperature of the electrode (Figure 1). The 


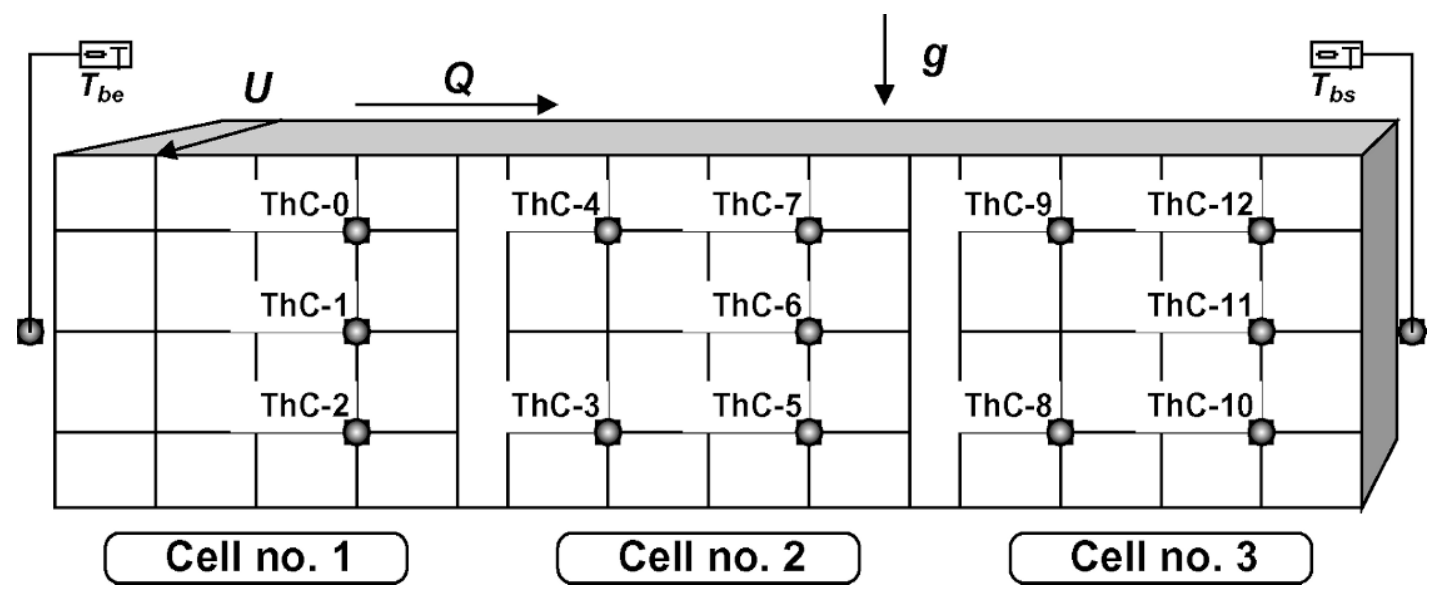

Figure 1. Thermocouple (ThC) location at the electrode surface vs. length and height (position $=x, y$; $g=$ gravity) for experiments with model fluids (dimensions $x_{\max }=738 \mathrm{~mm}$ and $y_{\max }=76 \mathrm{~mm}$; positions $x=186,306,432,552$, and $678 \mathrm{~mm}$ and $y=25,37.5$, and $50 \mathrm{~mm}$ ). $T_{b e}=$ product inlet temperature $\left({ }^{\circ} \mathrm{C}\right) ; U=$ electrical potential $(\mathrm{V}) ; Q=$ volume flow rate $\left(\mathrm{m}^{3} / \mathrm{s}\right) ; g=$ gravity $\left(\mathrm{m} / \mathrm{s}^{2}\right)$.

temperature difference, $T_{w}-T_{b}$ (where $T_{w}$ is the wall temperature and $T_{b}$ is the product temperature), under fouling-free conditions was then described by an empirical correlation.

With a Fouling Fluid (Whole Milk). The experimental fluid was whole milk (Danone, Bailleul, France). The thermal dependencies of physical properties (density, viscosity, thermal conductivity, specific heat capacity, electrical conductivity, and viscosity) were taken from the literature (Alais, 1975; Bertsch, 1981; El-Hajal, 1997) and are reported in Table 2.

A perfect knowledge of fouling that occurs within indirect UHT sterilization is essential to improve the design of this type of apparatus, as well as to compare it with other heating technologies. In this work, 5 different experiments were carried out whose experimental configurations and conditions are described in Table 3. Milk was sterilized according to the following steps:

1. Preheating from $T_{0}$ to $T_{1}$.

2. Homogenization at a pressure close to $20 \mathrm{MPa}$.

3. Heating from $T_{1}$ to $T_{2}$ in the heat recovery section (heater I),
4. Heating from $T_{2}$ to $T_{3}$ in heater II (a PHE with a hot water loop under pressure, or an ohmic heater).

5. Cooling to $T_{4}$ in the cooling section.

A counterpressure was maintained close to $550 \mathrm{kPa}$ in heater II (hottest point of the process) to prevent any boiling. Configuration 1 was carried out on a conventional PHE (V7 type; Vicarb France) and was used as a reference to analyze the deposit distribution (dry weight) and its chemical composition (lipid, protein, and mineral contents) vs. the bulb temperature. The temperature was regulated by increasing the water loop flow rate to modify the temperature profile. In configurations 2 to 5 , heater I remained a PHE but with a smaller surface area (V2 type; Vicarb France) and space between the plates (which increased its sensitivity to fouling), and heater II was replaced by an ohmic heater. Electrical $\left(2.7<P_{\text {elec }}<9.5 \mathrm{~kW}\right)$, thermal $\left(7.3<T_{3}-T_{2}\right.$ $<44.5^{\circ} \mathrm{C}$, and $0.34<T_{w}-T_{b}<1.91^{\circ} \mathrm{C}$ ), and hydraulic $(7,350>R e>3,540)$ constraints were progressively increased in the ohmic heater to evaluate its behavior during fouling by a real product (whole milk).

Table 1. Electrical conductivities of model fluids ${ }^{1}$

\begin{tabular}{ll}
\hline Fluid & Conductivity \\
\hline Water & G1: $\sigma=1.207+0.0216(T-20)$ \\
& G2: $\sigma=4.277+0.0964(T-20)$ \\
Sucrose solution, 50\% (wt/wt) & G3: $\sigma=15.76+0.349(T-20)$ \\
& G1: $\sigma=1.307+0.0311(T-20)+0.0004\left(T^{2}-20^{2}\right)$ \\
& G2: $\sigma=4.174+0.0945(T-20)+0.0012\left(T^{2}-20^{2}\right)$ \\
& G3: $\sigma=8.096+0.1801(T-20)+0.0024\left(T^{2}-20^{2}\right)$ \\
\hline
\end{tabular}

\footnotetext{
${ }^{1}$ Electrical conductivity $(\sigma, \mathrm{mS} / \mathrm{cm})$ between 20 and $80^{\circ} \mathrm{C} ; \mathrm{T}=$ temperature $\left({ }^{\circ} \mathrm{C}\right) ; \mathrm{G} 1, \mathrm{G} 2$, and $\mathrm{G} 3$ are reference solutions differing in electrical conductivity.
} 
Table 2. Physical and thermal properties of whole milk vs. temperature ${ }^{1}$

\begin{tabular}{lll}
\hline Property & Equation & Temperature \\
\hline Volume mass, $\mathrm{kg} / \mathrm{m}^{3}$ & $\rho=1035.66-0.2737 \cdot T-2.255 \cdot 10^{-3} \cdot T^{2}$ & $65<T<140^{\circ} \mathrm{C}$ \\
Viscosity, $\mathrm{mPa} \cdot \mathrm{s}$ & $\ln (\mu)=+0.666-1.951 \cdot 10^{-2} \cdot T+3.92 \cdot 10^{-5} \cdot T^{2}$ & \\
& $+L M \cdot\left(-4.37 \cdot 10^{-2}+1.674 \cdot 10^{-3} \cdot T-9.53 \cdot 10^{-6} \cdot T^{2}\right)$ & $70<T<135^{\circ} \mathrm{C}$ \\
& $+L M^{2} \cdot\left(9.83 \cdot 10^{-3}-1.739 \cdot 10^{-4} \cdot T+9.75 \cdot 10^{-7} \cdot T^{2}\right)$ & \\
Specific heat capacity, J/kg per K & $C=3692+2.976 \cdot T$ & $53<T<143^{\circ} \mathrm{C}$ \\
Thermal conductivity, W/m per K & $\lambda=0.511+2.4881 \cdot 10^{-3} \cdot T-1.5551 \cdot 10^{-5} \cdot T^{2}$ & $20<T<130^{\circ} \mathrm{C}$ \\
Electrical conductivity, S/m & $\sigma=0.5295+0.0119 \cdot(T-25)$ & $20<T<140^{\circ} \mathrm{C}$ \\
\hline
\end{tabular}

${ }^{1}$ From Alais (1975), Bertsch (1981), and El-Hajal (1997). $\rho=$ volume mass; $T=$ temperature; $\mu=$ viscosity; $L M=$ lipid content; $C=$ specific heat capacity; $\lambda$ = thermal conductivity; $\sigma=$ electrical conductivity.

In each case, heaters I and II were studied independently. The operating conditions and experimental measurements are reported in Tables 4 and 5, respectively. For the PHE, the overall heat transfer coefficient, $h_{\mathrm{g}}$, and pressure drop, $D P$, were recorded. At the end of each experiment, the PHE was dismantled and the dry weight of the deposit was measured when present in sufficient quantity. For the ohmic heater, the heat dissipation coefficient, $R h_{\mathrm{CO}}$, was monitored to compare the electrical and thermal performance, as was the pressure drop. In each experiment, an initial starting period was carried out using water. With the ohmic heater, the electrical conductivity of water was previously adjusted by sodium chloride adjunction as close as possible to that of milk to avoid over- or underheating. In configurations 4 and 5, the exchange surface of heater I was increased from 1.32 to $2.4 \mathrm{~m}^{2}$ to reduce its sensitivity to fouling. In configuration 4 , a long run was carried out, but milk was recycled after $7 \mathrm{~h}$; the objective was to observe whether the deposit properties in the ohmic heater evolved with time under constant thermal and hydraulic conditions. In configuration 5, the objective was to generate heavy fouling of the ohmic heater; to do so the flow rate was strongly reduced to increase the differences of temperature, $T_{3}-T_{2}$ $\left(44.5^{\circ} \mathrm{C}\right)$, wall overheating, $T_{w}-T_{b}\left(+1.9^{\circ} \mathrm{C}\right.$ under clean conditions), and residence time (28.3 s) and to work with a high electrical current (133 A).

\section{Numerical Simulation: SPC Version 1.0 Software and Simulated Conditions}

The software SPC version 1.0 (INRA, Paris, France) simulates the thermal performance of continuous processes during the stabilization of complex liquid food products. The aim of the software is 1 ) to simulate the thermal (temperature of the fluid, deposit, and wall) and hydraulic (pressure drop) performance of heat exchangers, 2) to take into account the impact of fouling, 3) to include the qualitative evolution of the product through chemical or biochemical kinetics, and 4) to compare the efficiency and working conditions of several technologies: a) cocurrent and b) countercurrent tubular heat exchangers, c) indirect and d) direct $\vec{E} \perp \vec{v}$, and e) $\vec{E} / / \vec{v}$ Joule effect heaters. The source code used was based on the theoretical analysis of the different technologies. To analyze the problems, the differential equations governing heat transfer were established. The equations governing the conservation of mass, momentum, and energy for an incompressible fluid were programmed. The differential equations were then solved numerically by one-dimensional resolution vs. the

Table 3. Experimental conditions and configurations 1 to 5 during UHT treatment of whole milk ${ }^{1}$

\begin{tabular}{llllll}
\hline & \multicolumn{5}{c}{ Configuration } \\
\cline { 2 - 6 } Condition & 1 & 2 & 3 & 4 & 5 \\
\hline Heater I & $\mathrm{V} 7(32 / 1)$ & $\mathrm{V} 2(11 / 3)$ & $\mathrm{V} 2(11 / 3)$ & $\mathrm{V} 2(21 / 3)$ & V2 $(21 / 3)$ \\
Heater II & $\mathrm{V} 7(22 / 1)$ & $\mathrm{OH}(5 / 1)$ & $\mathrm{OH}(5 / 1)$ & $\mathrm{OH}(5 / 1)$ & $\mathrm{OH}(5 / 1)$ \\
$Q, \mathrm{~L} / \mathrm{h}$ & 510 & 298 & 272 & 273 & 178 \\
Time, $\min$ & 560 & 335 & 277 & 710 & 195 \\
$T_{0},{ }^{\circ} \mathrm{C}$ & 5.0 & 9.5 & 7.8 & 8.0 & 7.0 \\
$T_{1},{ }^{\circ} \mathrm{C}$ & 72.0 & 65.5 & 60.0 & 81.0 & 48.9 \\
$T_{2},{ }^{\circ} \mathrm{C}$ & 120 & 132 & 116 & 106 & 93.7 \\
$T_{3},{ }^{\circ} \mathrm{C}$ & 138 & 139 & 137 & 134 & 138 \\
$T_{4},{ }^{\circ} \mathrm{C}$ & 87.0 & 72.0 & 122 & 108 & 96.5 \\
\hline
\end{tabular}

${ }^{1}$ For heaters I and II: name (number of passes/number of channels per pass). OH = ohmic heater; $Q=$ volume flow rate; $T$ = temperature. 
Table 4. Experimental results in heater I (plate heat exchanger) ${ }^{1}$

\begin{tabular}{|c|c|c|c|c|c|}
\hline \multirow[b]{2}{*}{ Result } & \multicolumn{5}{|c|}{ Configuration } \\
\hline & 1 & 2 & 3 & 4 & 5 \\
\hline$T_{2}-T_{1},{ }^{\circ} \mathrm{C}$ & 48.0 & 66.4 & 55.6 & 25.4 & 44.8 \\
\hline$R T, \mathrm{~s}$ & 63.7 & 19.9 & 21.8 & 41.5 & 63.5 \\
\hline$v, \mathrm{~m} / \mathrm{s}$ & 0.25 & 0.14 & 0.13 & 0.13 & 0.085 \\
\hline$R e$ & 4,050 & 1,500 & 1,150 & 1,170 & 540 \\
\hline$P_{\text {ther }}, \mathrm{W}$ & 28,161 & 22,816 & 17,317 & 7,981 & 9,043 \\
\hline$D P_{0}, \mathrm{~Pa}$ & $\approx 260$ & $\approx 20$ & $\approx 17$ & $\approx 30$ & $\approx 22$ \\
\hline$D P / D P_{0}$ & $1 \rightarrow 1.7$ & $1 \rightarrow 3.7$ & $1 \rightarrow 4.6$ & $1 \rightarrow 1.2$ & $1 \rightarrow 1.3$ \\
\hline$R h$ & $1 \rightarrow 1.3$ & $1 \rightarrow 1.25$ & $1 \rightarrow 1.22$ & $1 \rightarrow 1.5$ & $1 \rightarrow 1.25$ \\
\hline
\end{tabular}

${ }^{1}$ First figure corresponds to the beginning and the second to the end of the experiment. $T=$ temperature; $R T=$ mean residence time; $v=$ velocity $R e=$ Reynolds number $P_{\text {ther }}=$ thermal power $D P=$ pressure drop; $R h=$ reduced heat transfer coefficient.

length of the apparatus. A Runge-Kutta method with constant step was used because it provides a good compromise between accuracy and speed for convergence criteria based on thermal and mass balance.

Simulated conditions were the pasteurization of whole milk (heating from 50 to $92^{\circ} \mathrm{C}, Q=200 \mathrm{~L} / \mathrm{h}, R T=$ 15 to $16 \mathrm{~s}$, where $R T$ is mean residence time) with a variable deposit at the electrode surface. The ohmic heater was composed of 3 rectangular cells in series ( $e=15 \mathrm{~mm}, w=76 \mathrm{~mm}$, and $L=246 \mathrm{~mm}$ ), and a discretization with 100 steps along the length was performed. The SPC version 1.0 software provides local values of thermal and hydraulic parameters as well as dimensionless numbers and physical properties of the fluid. The hypotheses and boundary conditions used to solve the problem are as follows:

- The geometry of the channel is uniform $(L=246$ $\mathrm{mm}, w=76 \mathrm{~mm}$, and $e=15 \mathrm{~mm}$ ) and the 3 active cells are located in series.
- The thickness of the deposit is assumed to be constant along the electrode surface $\left(0<e_{d}<4 \mathrm{~mm}\right)$,

- All physical properties are assumed to depend on temperature, except the thermal and electrical conductivities of the deposit $\left(\lambda_{\text {ther }}=0.6 \mathrm{~W} / \mathrm{m} / \mathrm{K}\right.$, $\left.\sigma_{20}{ }^{\circ} \mathrm{C}=0015 \mathrm{~S} / \mathrm{m}\right)$.

- The fluid is considered to form a homogeneous mixture with constant and uniform velocities (no velocity profiles, piston model) along the apparatus.

- The wall of the heater is assumed to be adiabatic.

- At the channel entrance, the temperature and velocity exhibit a uniform distribution.

- The heat transfer coefficient between the deposit (subject to the Joule effect) and the fluid is given by the correlation of Churchill and Ozoë (1973), as cited in Brienza et al. (1983).

- $T_{w}-T_{b}$ is null under fouling-free conditions $\left(e_{d}=\right.$ $0 \mathrm{~mm}$ ).

Table 5. Experimental results in heater II (plate heat exchanger and ohmic heater) ${ }^{1}$

\begin{tabular}{|c|c|c|c|c|c|}
\hline \multirow[b]{2}{*}{ Result } & \multicolumn{5}{|c|}{ Configuration } \\
\hline & 1 & 2 & 3 & 4 & 5 \\
\hline$T_{w}-T_{b}$ at $\mathrm{t}=0,{ }^{\circ} \mathrm{C}$ & - & 0.34 & 0.96 & 1.41 & 1.91 \\
\hline$T_{3}-T_{2},{ }^{\circ} \mathrm{C}$ & 18.0 & 7.3 & 21.6 & 27.7 & 44.5 \\
\hline$R T, \mathrm{~s}$ & 43.8 & 16.9 & 18.6 & 18.5 & 28.3 \\
\hline$v, \mathrm{~m} / \mathrm{s}$ & 0.25 & 0.073 & 0.066 & 0.066 & 0.043 \\
\hline$R e$ & 5,930 & 7,350 & 6,070 & 5,690 & 3,540 \\
\hline$U, \mathrm{~V}$ & - & 24.4 & 36.7 & 43.7 & 41.5 \\
\hline$I, \mathrm{~A}$ & - & 65.1 & 112.7 & 126.7 & 133.1 \\
\hline$P_{\text {ther }}, \mathrm{W}$ & 10,741 & 2,538 & 6,857 & 8,805 & 9230 \\
\hline$P_{\text {elec }}, \mathrm{W}$ & - & 2,754 & 7,178 & 9,591 & 9575 \\
\hline$E E, \%$ & - & 92.2 & 95.5 & 91.8 & 96.4 \\
\hline$D P_{0}, \mathrm{~Pa}$ & $\approx 180$ & $\approx 10$ & $\approx 10$ & $\approx 10$ & $\approx 10$ \\
\hline$D P / D P_{0}$ & $1 \rightarrow 1.7$ & NS & NS & NS & NS \\
\hline$r_{d}+r_{p}, \Omega$ & - & $0.65 \rightarrow 0.65$ & $0.55 \rightarrow 0.6$ & $0.6 \rightarrow 0.6$ & $0.5 \rightarrow 1.3$ \\
\hline$R h_{\mathrm{CO}}$ & - & $1 \rightarrow 0.96$ & $1 \rightarrow 0.99$ & $1 \rightarrow 0.93$ & $1 \rightarrow 0.72$ \\
\hline
\end{tabular}

${ }^{1}$ First figure corresponds to the beginning and the second to the end of experiment. $T_{w}=$ wall temperature; $T_{b}=$ product temperature; $T=$ temperature; $R T=$ mean residence time; $v=$ velocity; $R e=$ Reynolds number; $U=$ electrical potential; $I=$ current; $P_{\text {ther }}=$ thermal power; $P_{\text {elec }}=$ electrical power; $E E=$ energy efficiency; $D P=$ pressure drop; $r_{d}=$ deposit electrical resistance; $r_{p}=$ product electrical resistance; $R h_{\mathrm{CO}}=$ heat dissipation coefficient. 


\section{RESULTS AND DISCUSSION}

\section{Study of Wall Temperature Without Fouling}

Temperature Profile and Energy Balance. The thermal performance of the ohmic heater was investigated vs. the flow regimen $(50<R e<5000)$, power supplied $(0<P<15 \mathrm{~kW})$, and electrical conductivity of the fluids $\left(0.1<\sigma_{20}{ }^{\circ} \mathrm{C}<2 \mathrm{~S} / \mathrm{m}\right)$. This protocol enabled a global thermal approach (thermal and electrical balance, modeling of the temperature profile of the fluid) and a local analysis of the wall temperature of the electrode. For $\mathrm{OH}$, the equation of conservation of energy (Eq. [1]) was solved under several assumptions to determine an analytical expression (Eq. [2]) of the temperature profile (Fillaudeau, 2004):

$$
\begin{gathered}
\rho \cdot \mathrm{C} \cdot \frac{d T}{d t}=\nabla \cdot(\lambda \cdot \nabla T)+\sigma \cdot|\nabla U|^{2}+\Phi_{V} \\
T_{b}(x)=\frac{1}{m} \cdot\left[\left(1+m \cdot T_{b e}\right) \cdot \exp \left(\frac{m \cdot \sigma_{0} \cdot S P \cdot E^{2}}{Q \cdot \rho \cdot C} \cdot x\right)-1\right]
\end{gathered}
$$

First, the thermal and electrical balance was established with 160 working conditions. The equality between thermal and electrical powers, $\left(P_{\text {elec }}-P_{\text {ther }} / P_{\text {ther }}\right)$ $< \pm 5 \%$, showed that the energy conversion was close to $100 \%$ :

$$
\begin{gathered}
Q \cdot \rho \cdot C \cdot d T= \\
\sigma_{0} \cdot(1+m \cdot T) \cdot E^{2} \cdot S P \cdot d x \text { with } E=U / e .
\end{gathered}
$$

Second, the analytical expression of the temperature profile, $T_{b}$, and measurements of the wall temperature, $T_{w}$, (ThC-0 to ThC-12) enabled the comparison and discussion of temperature profiles $\left(T_{b}, T_{w}\right)$ vs. the axial position and the height (Figure 2). The temperature gradient, $T_{w}-T_{b} \approx T_{w}-T_{b \text { lin }}$ constitutes an important criterion. The temperature gradient, $T_{w}-T_{b}$, increases vs. the heat power and decreases with the Reynolds number. This point is fundamental but requires being checked and modeled if the heat treatment of the fouling fluid is to be considered. Usually, the thermal profiles, $T_{b}(x)$ and $T_{w}(x)$, are parallel curves, which indicate a temperature gradient, $T_{w}-T_{b}$, that is almost constant along the heater. However, under specific flow and heat conditions, a strong divergence of temperature profiles, $T_{w}(x)$ and $T_{b}(x)$, was observed, characterized by different wall temperatures at the bottom and the top of a section (Ould El Moctar et al., 1993; El Hajal et al., 1998). In fact, the thermophysical properties of a liquid in flow are dependent on temperature, and the temperature field in turn depends on the residence time. Natu- ral convection can occur and generate additional movement to the main flow, and implies a mixed convection regimen. In the conditions studied here, we considered that mixed convection occurred if the standard deviation of wall temperatures in the same section (e.g., ThC5 , ThC-6, and ThC-7) was greater than 5 times the ThC precision (Beuf et al., 2001).

Analysis of Wall Overheating. The temperature gradient, $T_{w}-T_{b}$, should remain as shallow as possible for the successful treatment of fouling liquid food. The main goal is to reach a temperature difference equal to or lower than those commonly generated with a PHE $\left(<+0.5^{\circ} \mathrm{C}\right.$, most of the time +0.2 or $\left.+0.3^{\circ} \mathrm{C}\right)$. Consequently, the quantification and modeling of the temperature gradient appears essential. In Figure 3, the evolution of the temperature gradient, $T_{w}-T_{b}$, is reported for all experimental conditions (flow regimen, heat power, and electrical conductivity), excluding mixed convection phenomena. An increase in the temperature gradient, $T_{w}-T_{b}$ (maximal value close to $+10^{\circ} \mathrm{C}$ ), was observed when the heat power was increased and the flow regimen decreased. For a given flow regimen, the evolution of $T_{w}-T_{b}$ exhibited a linear shape vs. the heat fouling power. The slope, $a=\left(T_{w}-T_{b}\right) / P$ (Eq. [4]), was calculated and an empirical correlation established for $50<R e<$ $4,500,0<P<10^{+4} \mathrm{~W}$, and $0.1<\sigma_{20^{\circ} \mathrm{C}}<2 \mathrm{~S} / \mathrm{m}$, which enabled the temperature gradient, $T_{w}-T_{b}$, to be estimated and pure-volume and direct-resistance heating $\left(T_{w}-T_{b}<0.5^{\circ} \mathrm{C}\right)$ to be defined:

$$
\alpha=\frac{T_{w}-T_{b}}{P}=0.0405 \cdot R e^{-0.65} \text { with } R^{2}=0.8963 .
$$

\section{UHT Sterilization of Whole Milk}

The aim of this work was to gain insight into the ability of $\mathrm{OH}$ to ensure the UHT treatment of whole milk compared with a heat exchanger system. Special care was taken to investigate the heat transfer phenomena, that occur over a range of temperatures from 105 to $138^{\circ} \mathrm{C}$. This temperature range corresponds to the critical part of the process causing protein and mineral fouling. The objectives were 1) to show the suitability of $\mathrm{OH}$ in the heat treatment of milk, 2) to study the thermal and hydraulic performance with increasing power and temperature differences between the inlet and outlet of the ohmic heater, 3) to define and validate a criterion to follow the heat dissipation efficiency, and 4) to compare the fouling propensity with different configurations.

Heat Dissipation Coefficient, $\boldsymbol{R h}_{\mathrm{CO}}$. The definition of the heat dissipation coefficient in the ohmic heater, $R h_{\mathrm{CO}}$, was based on the following assumption: "The contact between a fluid (food product) and a surface 


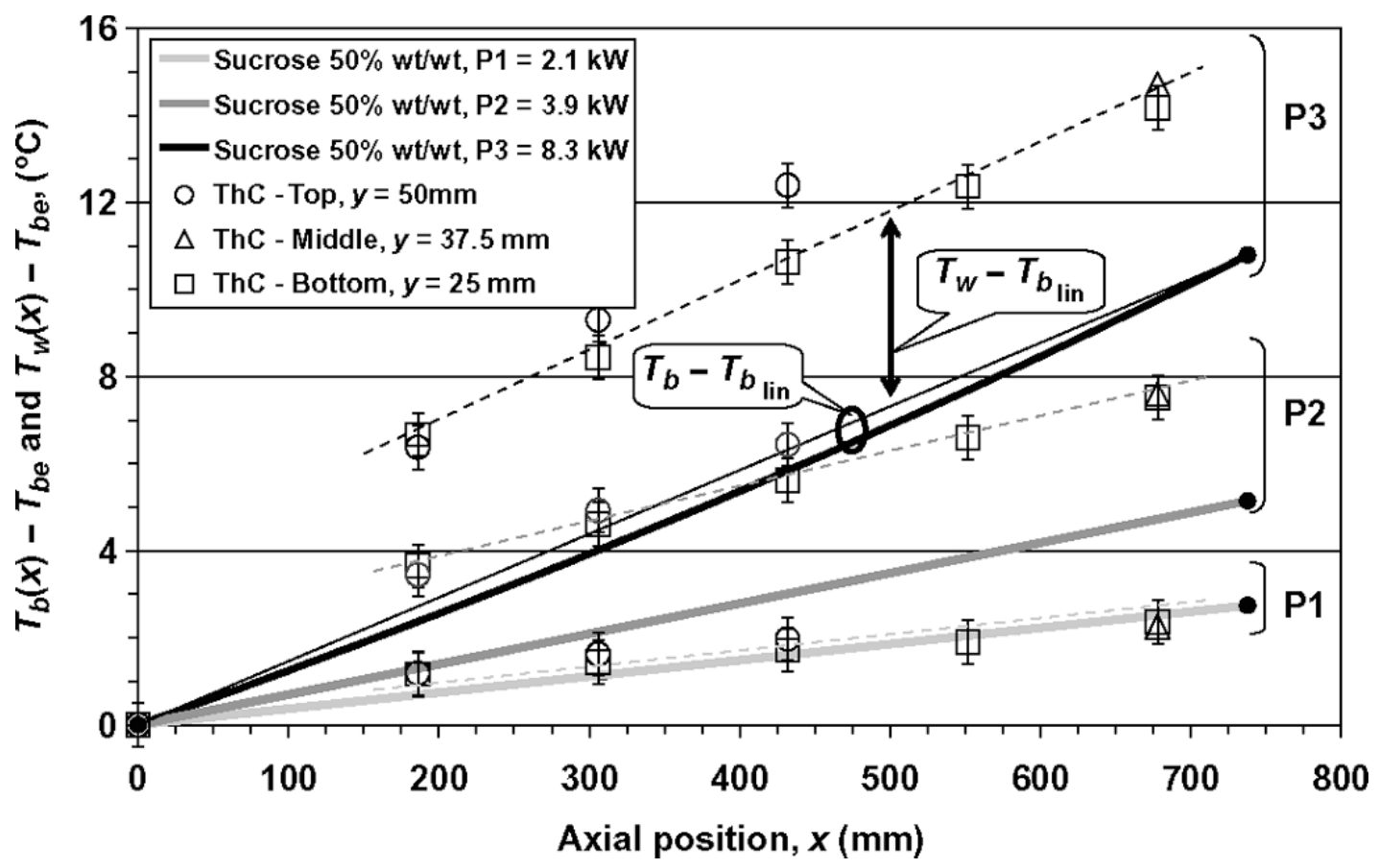

Figure 2. Temperature profiles for fluid $\left[T_{b}(x)-T_{b e}, T_{b l i n}(x)-T_{b e}\right.$, and $\left.T_{w}(x)-T_{b e}\right]$ vs. length $(x)$ and heat power [sucrose solution, $50 \%$ (wt/wt); electrical conductivity, G3; $\left.Q=700 \mathrm{~L} / \mathrm{h} ; T_{b e}=20^{\circ} \mathrm{C}\right] . T_{b}(x)=$ thermal profile of the product; $T_{b e}=$ product inlet temperature; $T_{w}(x)=$ thermal profile of the wall; ThC = thermocouple; $T_{b}=$ product temperature; $T_{b l i n}=$ linear thermal profile; $T_{w}=$ wall temperature; P1, P2, and P3 = heat power at $2.1,3.9$, and $8.3 \mathrm{kw}$.

(electrode) implies the occurrence of interactions. These interactions may induce a deposit on the surface whose growth kinetics may be driven by a temperature difference or chemical reactions due to temperature. If the deposition occurs then the thermal and electrical properties of the deposit will have consequences on heat transfer mechanism as well as on process performance" (Fillandeau et al., 2001).

Ohmic heating presents several advantages, but for efficient implementation in the food industry, different factors such as the fouling propensity and electrical conductivity of deposits have to be considered and accurately quantified. When fouling occurs, additional electrical resistance can be created at the surface of the electrodes, resulting in a new electrical system. This layer is motionless and the Joule effect occurs there, just as it does in the flowing product. In any case, the electrical resistance of the layer will determine the performance of the system. In this new formulation (Eq. [5]), the first term corresponds to heat generated in the deposit and the second to that in the flowing product:

$$
P_{\text {elec }}=I^{2} \cdot\left(r_{d}+r\right)=I^{2} \cdot\left(\frac{1}{\sigma_{d}} \cdot \frac{e_{d}}{S}+\frac{1}{\sigma} \cdot \frac{e-e_{d}}{S}\right) .
$$

Heat generated in this layer may be transferred to the fluid through heat convection or may induce reactions inside the deposit by a temperature increase. The balance will be a complex equilibrium between the properties of the layer (electrical and thermal conductivity, temperature sensitivity) and the heat transfer coefficient, depending on the hydraulic conditions.

An increase in electrical resistance from fouling induces a potential drop. The fluid is also less well heated, implying an increase in the global voltage required to maintain performance levels. If the deposit constitutes electrical resistance, the electrical consumption should be increased to deliver the same thermal power. To follow the fouling effect in the ohmic heater, a criterion is defined-the heat dissipation coefficient, $R h_{\mathrm{CO}}$ (Eq. [6]) - based on electrical $(I, U)$ and thermal $\left(Q, \rho, C, T_{2}\right.$, $T_{3}$ ) power. This ratio is considered under clean conditions $(\mathrm{t}=0)$ vs. time $(\mathrm{t})$. If a deviation of the heat dissipation coefficient, $R h_{\mathrm{CO}}$, is observed, this means that fouling induces additional energy dissipation:

$$
R h_{\mathrm{CO}}=\frac{\left(\frac{P_{\text {elec }}}{P_{\text {ther }}}\right)_{t=0}}{\left(\frac{P_{\text {elec }}}{P_{\text {ther }}}\right)_{t}} .
$$

Configuration 1: Fouling of a PHE. Plate heat exchangers are commonly used in UHT treatment of milk because of their compactness and high thermal 


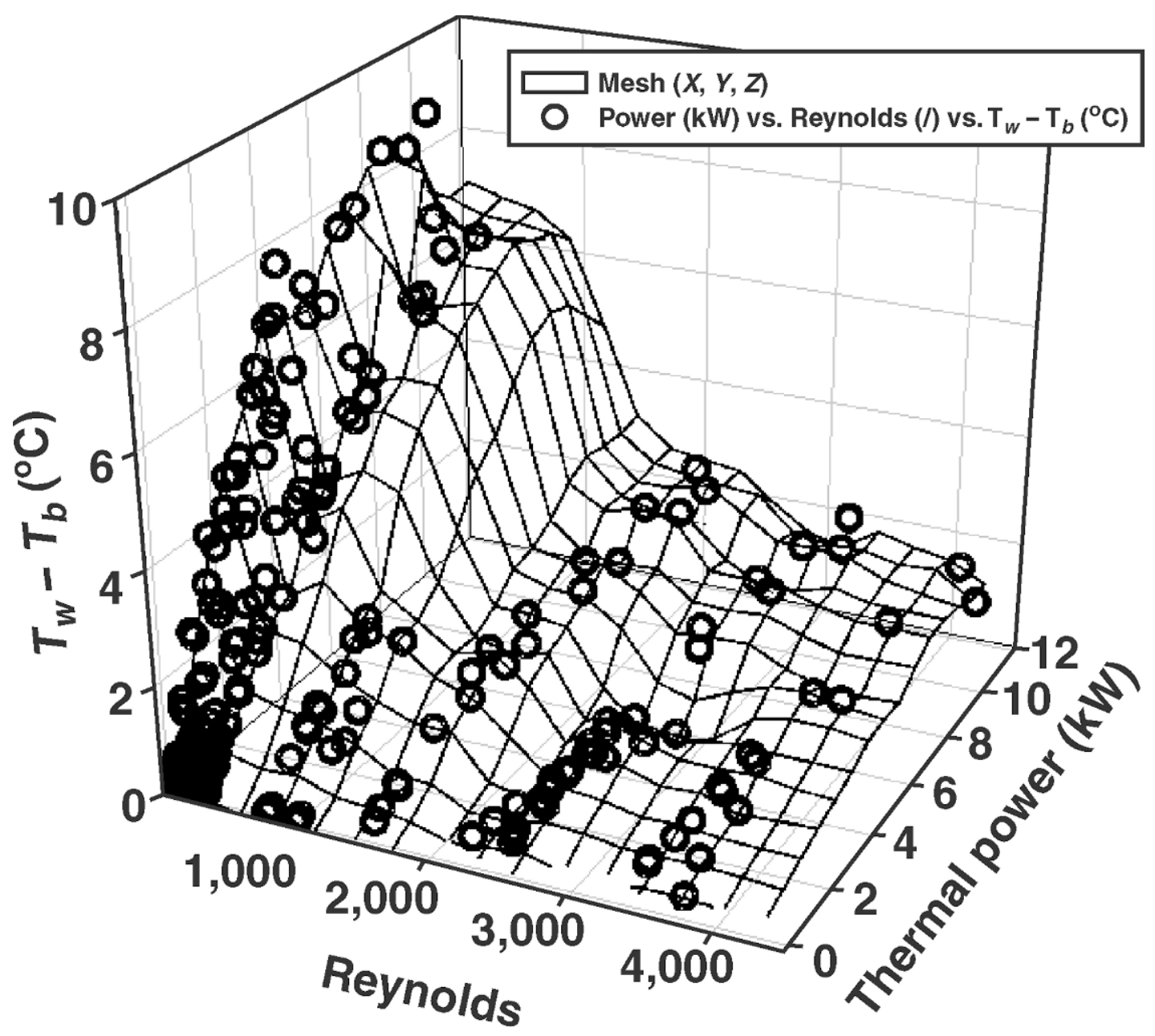

Figure 3. Temperature difference $\left(T_{w}-T_{b}\right)$ vs. heat power and flow regimen [water and sucrose solution, 50\% (wt/wt); electrical conductivities, G1, G2, and G3; $x=432 \mathrm{~mm} ; T_{w}=$ ThC-7]; $T_{w}=$ wall temperature; $T_{b}=$ product temperature.

performance. Knowing how fouling occurs in indirect UHT sterilization has been essential for improving the design of this type of apparatus and especially for increasing its working time between cleanings (Lalande et al., 1984; Tissier et al., 1984). The fouling of PHE surfaces during the heat treatment of milk has been studied in terms of kinetics of formation and chemical composition (Lyster, 1965; Burton, 1968; Tissier et al., 1984). Two kinds of deposits can be distinguished: types A and B (Lyster, 1965; Burton, 1968). A type A deposit is created at temperatures close to $100^{\circ} \mathrm{C}$. It is composed of proteins (50 to 60\%), minerals (30 to $35 \%$ ), and fat (around 1\%). It has a spongy appearance and a creamy white color. The type B deposit appears at temperatures exceeding $105^{\circ} \mathrm{C}$. The deposit composition is identified as minerals $(70 \%)$ and a small proportion of proteins (15 to $20 \%$ ) and fat (4 to $8 \%$ ). It strongly adheres to the surface and is hard, dense, and compact. Tissier et al. (1984) determined the following average compositions of protein deposits: For type A, the composition was $62 \% \beta$-LG, 9\% Ig, 9\% $\alpha$-LA, and 9\% $\kappa$-CN; for type B, it was $50 \% \kappa$-CN and $27 \% \alpha_{\mathrm{sl}} \mathrm{CN}$.

Fouling of the heat exchanger was observed during the experiments through the pressure drop and overall heat transfer coefficient measurements. Pressure drops give a useful indication of the geometrical change within flow channels when fouling takes place. However, because the change in pressure drop with time can be completely different among trials performed under the same conditions (Delplace et al., 1994), the overall heat transfer coefficient seemed to be the most representative measured consequence of the fouling layer formed on heat transfer surfaces. In heaters I and II, the results showed that the thermal and hydraulic performance and the analysis of the deposit were similar to previous works (Delplace, 1995). The pressure drop and thermal resistance increase in classical shapes, including an induction, a fouling, and postfouling period 


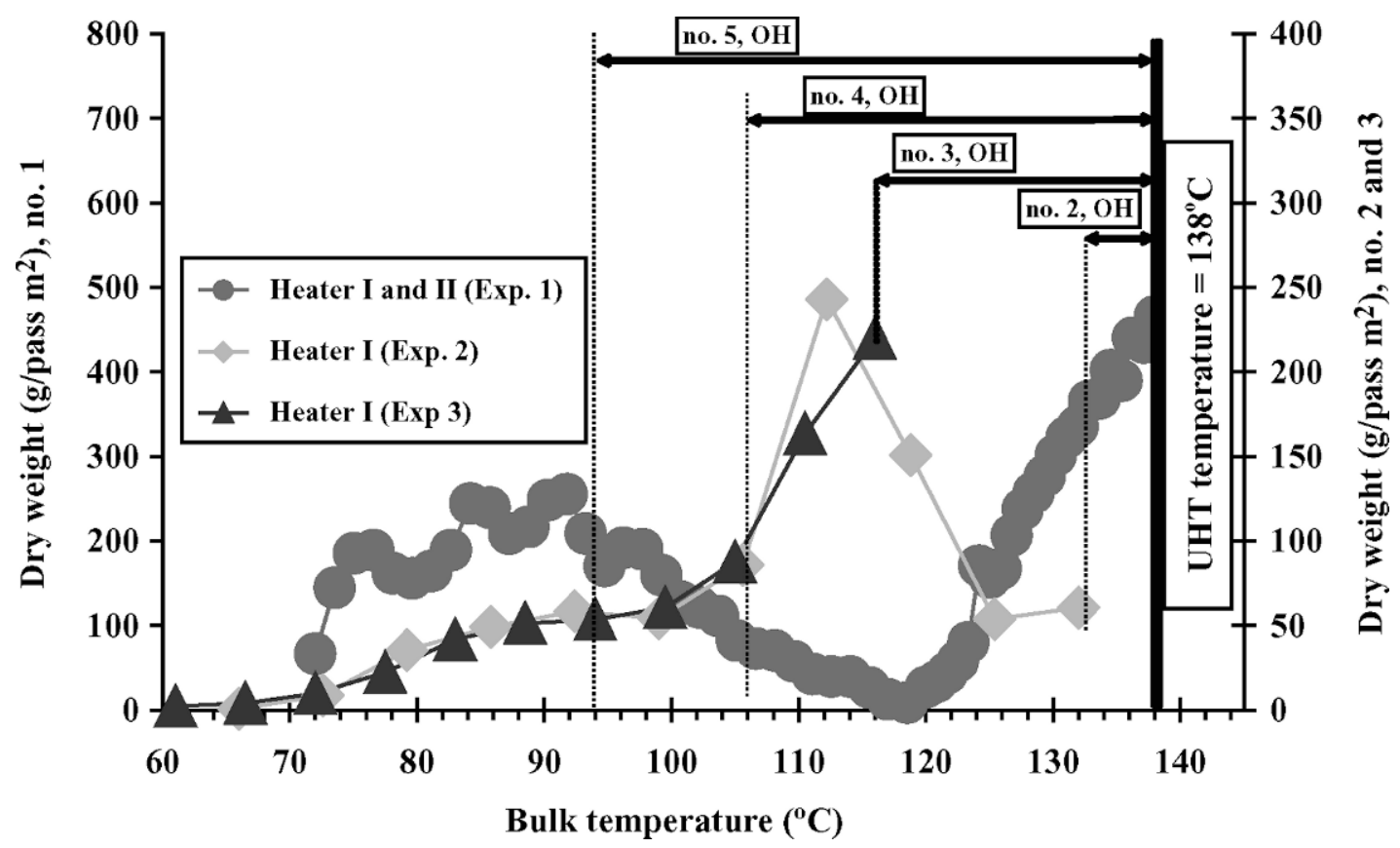

Figure 4. Dry weight of deposit in heater I vs. bulk temperature (not quantified in configurations 4 and 5). Comparison of configurations 1 (Lalande et al., 1984; Tissier et al., 1984), 2, and 3, and temperature range included in the ohmic heater (OH).

(Delplace, 1995; Delplace and Leuliet, 1995). In this configuration, the duration of the experiment is limited by the exacerbation of the pressure drop.

Configurations 2 to 5: Fouling of the Ohmic Heater. In heater I (PHE), the change in pressure drop with time (Table 4) exhibits a classical shape for a PHE (configuration 1) and supports data from the literature (Lalande et al., 1984; Delplace, 1995; Delplace and Leuliet, 1995) showing that fouling increases with temperature and decreases with a larger heat exchange surface area and space between plates. The heat transfer resistance, $R h$, evolves in the same way as pressure drops because of the effect of fouling intensity. Configurations 2 to 5 confirmed that an efficient energy recovery unit should be used in association with an ohmic heater to carry out long tests (Table 4). Figure 4 represents the evolution of deposit dry weight along heater I vs. bulk temperature. When the temperature was greater than $100^{\circ} \mathrm{C}$, the fouling propensity drastically increased. We did not observe 2 separate peaks, as mentionned by Lalande et al. (1984), but did observe a regular increase in the amount of deposit with temperature, as reported by Burton (1968).

In contrast, in heater II (the ohmic heater) the performance remained constant, as shown in Table 5. The temperature regulation through electrical parameters (intensity, tension) was nearly perfect, even during the transition from water to milk. Slight overheating $\left(+2^{\circ} \mathrm{C}\right.$ to the regulated value) was observed for $10 \mathrm{~min}$ in con- figuration 3 , which was the consequence of a conductivity change between the water and milk. At this point, the power supplied by the ohmic heater provided acceptable performance. First, the variation in the pressure drop with time in heater II was not significant (Table 5 ), with the value remaining smaller than $2 \mathrm{kPa}$. The constant value of the pressure drop in the ohmic heater may be explained by the large space between the plates $(e=15 \mathrm{~mm}$ ) in comparison with the PHE (Vicarb, type $\mathrm{V} 2$, with $e=2.5 \mathrm{~mm}$ ). Energy efficiency was remarkable, remaining higher than $90 \%$. The heat dissipation coefficient, $R h_{\mathrm{CO}}$, with a value close to 1 (precision \pm 0.1 ), showed that there was no significant deviation of electrical consumption (except in configuration 5) in spite of the existence of a layer of deposit at the surface of the electrode. As shown in Figures 5A to 5C, a propensity to fouling was observed in cell 3 , in agreement with the operating conditions. Fouling appeared to be homogeneous along the electrode surface. Experiment 4 demonstrated that deposit properties remained constant even during long runs ( $7 \mathrm{~h}$ under fouling conditions, followed by $5 \mathrm{~h}$ with recycled milk) when process parameters were well controlled. In contrast, configuration 5 demonstrated a rapid and irreversible fall of the thermal and electrical parameters (Figure 6) linked to fouling intensity and thermal degradation at the electrode surface (Fillaudeau et al., 2001). Figure 5D (cell 3, configuration 5) shows thermal degradation of the deposit, with the appearance of small, blackened craters (burning). 

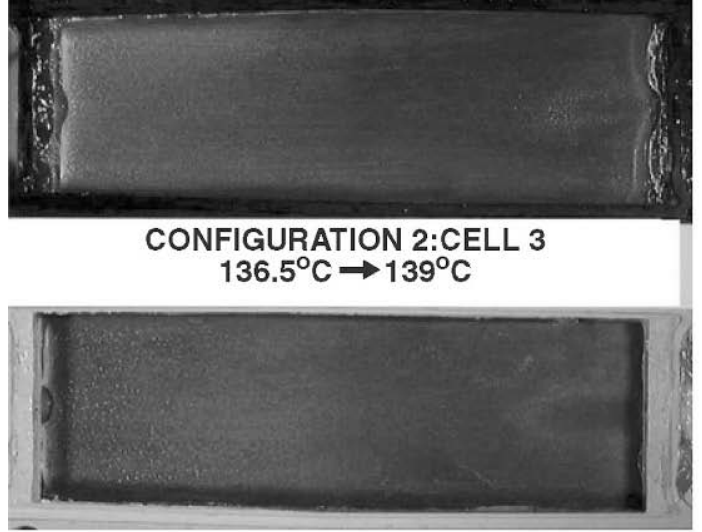

A

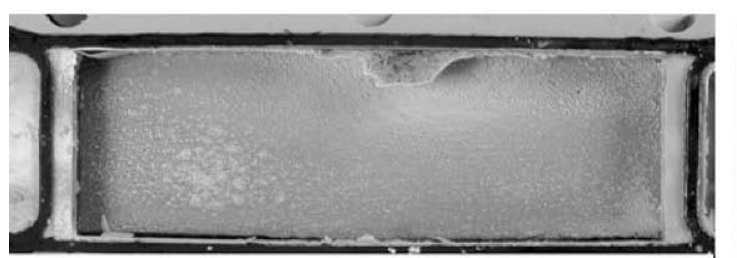

CONFIGURATION 4:CELL 3 $124.7^{\circ} \mathrm{C} \rightarrow 134^{\circ} \mathrm{C}$

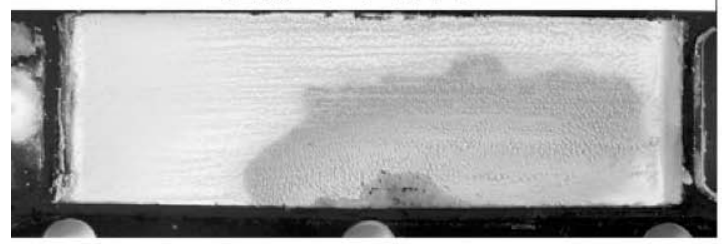

C

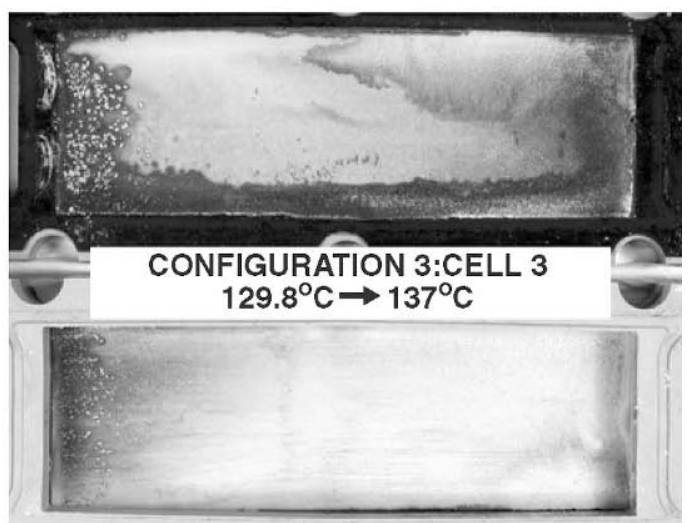

B

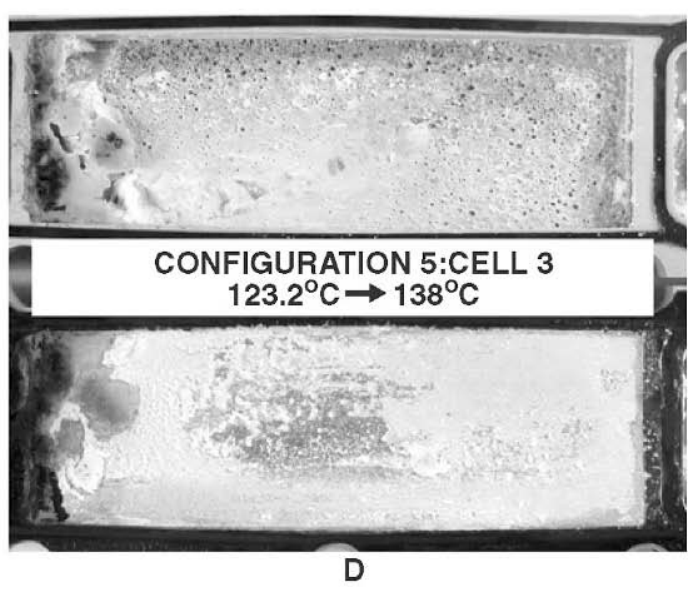

Figure 5. Observation of fouling generated by whole milk in cell 3 of the ohmic heater after Experiments 2 (A), 3 (B), 4 (C), and 5 (D).

The following explanations are proposed concerning 1) the observation of fouling at the electrode surface and 2 ) the deviation of $R h_{\mathrm{CO}}$ in the last configuration. The existing literature (Lalande et al., 1984; Delplace and Leuliet, 1995; Delplace et al., 1997) has demonstrated that for PHE, the fouling propensity increases with the bulk temperature and the temperature difference, $T_{w}-$ $T_{b}$. Wall overheating under fouling-free conditions was deduced from Equation 4. The values calculated (Table 5) ranged from 0.34 to $1.91^{\circ} \mathrm{C}$, constituting a significantly high value compared with conventional PHE. When fouling occurs, a Joule effect takes place in the static deposit. The heat generated in this layer should be transferred to the fluid by convection, but in fact, it induced an increase in the wall temperature (Fillaudeau et al., 2001; Ayadi et al., 2004). A physical threshold was reached when the heat generated inside the deposit could not be evacuated, and a drift of the electrical and thermal parameters was observed ( $R h_{\mathrm{CO}}$ collapse), which indicated thermal degradation of the deposit (burning due to the Joule effect).
Configurations 1 and 4: Observation of the Deposit. Configurations 1 and 4, which were similar long runs with 2 different technologies (PHE and $\mathrm{OH}$ ), were compared in the temperature range of 105 to $138^{\circ} \mathrm{C}$. Several parameters were held constant, such as the flow rate:surface area ratio (potential fouling area, potential amount of deposit) and the velocity of the temperature increase $\left(+0.7^{\circ} \mathrm{C} / \mathrm{s}\right)$ in heater I. Flow regimens $(R e$ $\approx 6,000$ ) were similar in heater II, but they were not really comparable because of the large geometrical differences. The reduced pressure drop, reduced heat transfer resistance, and heat dissipation coefficient in heater II for configuration 1 increased drastically, whereas in configuration 4, they remained constant. This illustrates that during UHT treatment of milk, the PHE was much more sensitive to fouling than the ohmic heater. In the ohmic heater, the heat transfer resistance and pressure drop remained constant and stable with time in spite of deposits being observed at the surface of the electrodes.

In configuration 4, the deposit in the ohmic heater was compared to classical fouling occurring in the PHE 


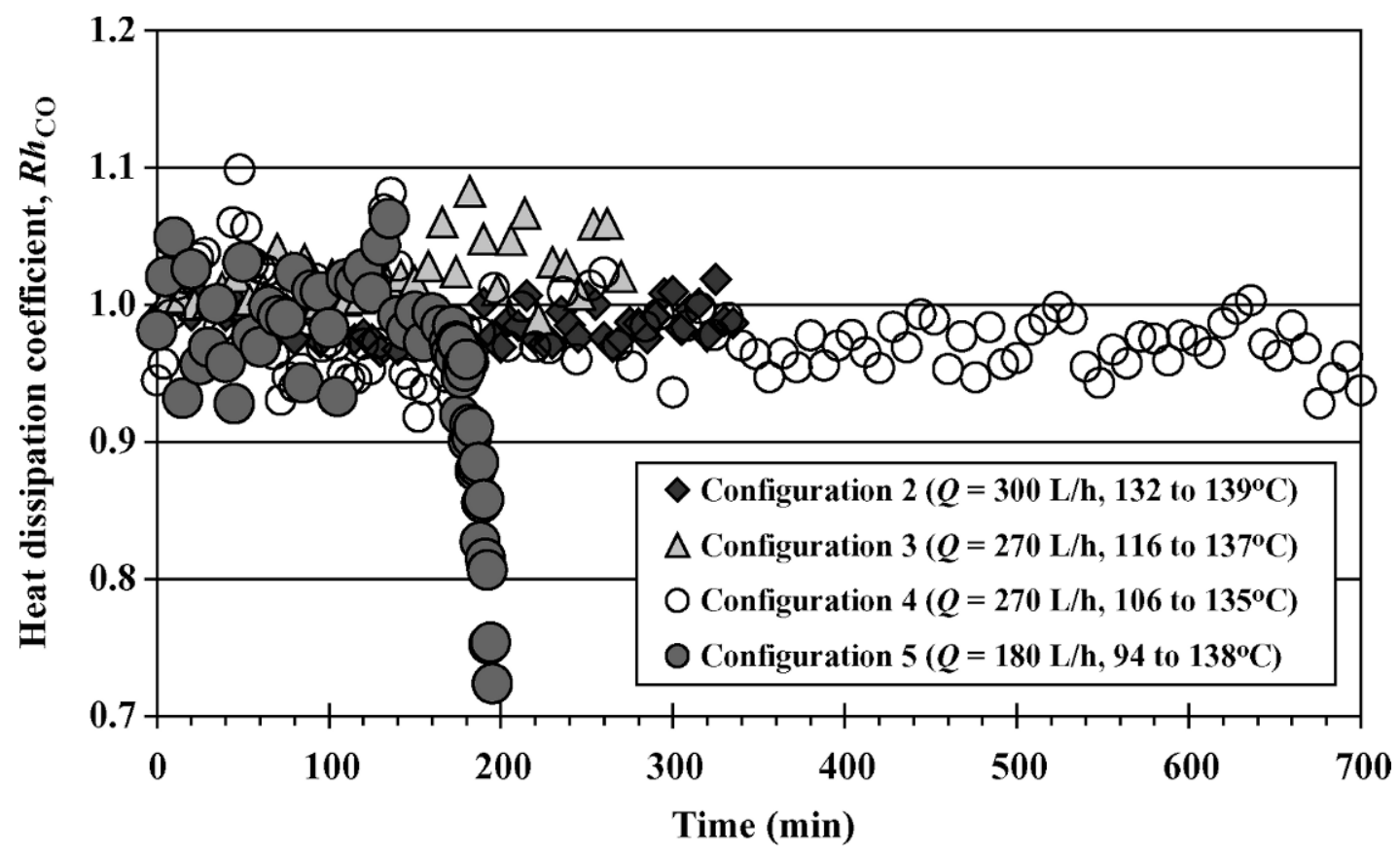

Figure 6. Heat dissipation coefficient vs. time in the ohmic heater (configurations 2 to 5 ). $R h_{\mathrm{CO}}=$ heat dissipation coefficient; $Q=$ volume flow rate $\left(\mathrm{m}^{3} / \mathrm{s}\right)$.

(configuration 1). Between 105 and $120^{\circ} \mathrm{C}$ (ohmic cells 1 and 2), the deposit formed appeared similar to a type A deposit. It was voluminous and spongy like a protein deposit. Its average thickness was $0.5 \mathrm{~mm}$ and its outer surface seemed to form curls, parallel to the fluid flow. The color of the deposit was creamy white. From $120^{\circ} \mathrm{C}$ up to $135^{\circ} \mathrm{C}$ (ohmic cell 3, Figure 5C), the appearance of the deposit changed markedly. It corresponded to a type B deposit (i.e., it was hard, dense, and had cracks). It adhered strongly to the wall, as would a fine mineral deposit called "milkstone," with a color varying from gray to yellow. Consequently, major fouling occurred in the ohmic heater without significant deviation of its hydrodynamic, thermal, or electrical parameters.

\section{Numerical Investigation of Electrode and Deposit Overheating with Fouling}

Overheating of poorly conducting liquids adjacent to hot surfaces not only causes burning or degradation of the liquids, but also leads to heat exchanger fouling. The local temperature in a direct Joule effect heater is then fundamental and can be determined either by physical measurement (i.e., magnetic resonance imaging; Ye et al., 2003) or by numerical simulation using a control volume code (Ould El Moctar et al., 1993).

The temperature profiles of fluid, $T_{b}$, deposit, $T_{d}$, and electrode surface, $T_{w}$, vs. heat exchanger length with a deposit thickness ranging from 0 to $4 \mathrm{~mm}$ was simulated with the SPC version 1.0 software. For an element $d x$, the joules generated inside the deposit are proportional to its thickness: Heat generated in this layer should be transferred to the fluid by convection. The thermal balance among the fluid, the deposit, and the electrode results from the physical $(\rho, C, \lambda, \mu)$ and electrical $(\sigma)$ properties of the fluid and the deposit. In addition, the flow conditions at the deposit-fluid interface define the magnitude of the heat convection coefficient. The mean temperature gradients between the electrode surface and bulk milk, $T_{w}-T_{b}$, and between the deposit surface and bulk milk, $T_{d}-T_{b}$, plotted for an ohmic heater vs. the deposit thickness (Figure 7) exhibit an exponential shape. The Joule effect inside the deposit causes overheating of the wall that makes fouling spiral out of control, because the fouling mechanism undergoes a "snowball effect." This phenomenon appears to be specific to the ohmic heater (direct Joule effect and $\vec{E} \perp \vec{v}$ ) and is related to a strong interaction between the Joule effect inside the deposit and the convective transfer at its surface.

Delplace et al. (1997) reported that the denaturation kinetics of whey protein were temperature dependent and demonstrated that in a PHE, denatured protein in the thermal boundary layer is involved in deposit formation, with a contribution of local hydrodynamics. In a realistic configuration with an ohmic heater, a velocity difference between the fluid flowing in the core and the fluid flowing close to the electrode (boundary 


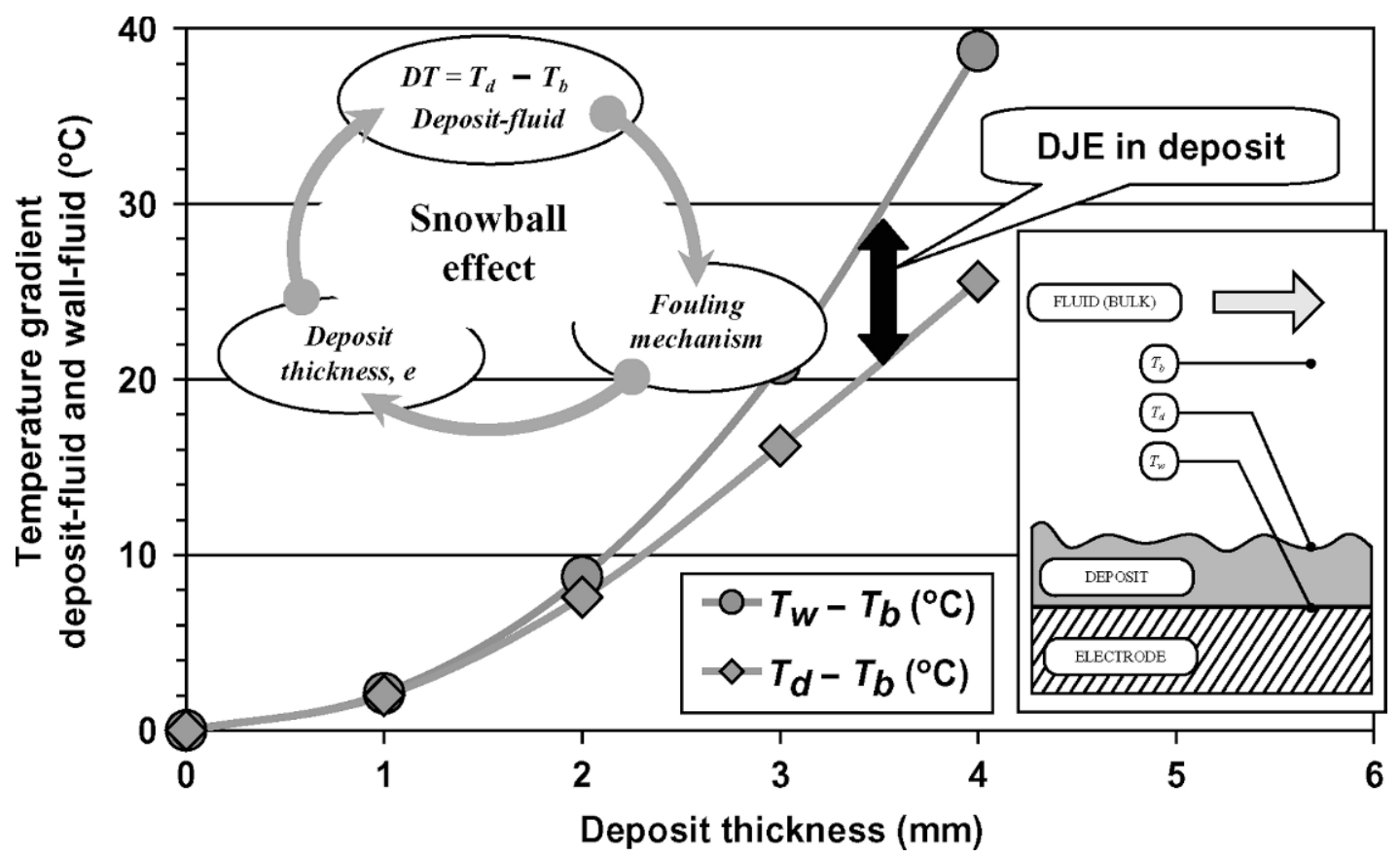

Figure 7. Evolution of the mean temperature differences, $T_{w}-T_{b}$ and $T_{d}-T_{b}$, along the ohmic heater vs. the deposit thickness (fluid, whole milk; $Q=200 \mathrm{~L} / \mathrm{h} ; T_{b e}=50^{\circ} \mathrm{C} ; T_{b s}=92^{\circ} \mathrm{C}$ ). Software used was SPC, version 1.0 (INRA). $D T=T_{d}-T_{b} ; T_{d}=$ deposit temperature; $T_{b}=$ product temperature; $T_{w}=$ wall temperature; DJE = direct Joule effect.

layer) does exist; thus, the temperature gradient in clean conditions (without fouling; Eq. [4]) can generate a driving force to initiate fouling. Numerical simulation consolidates the experimental results obtained during heat treatment of whole milk, showing that instability of the thermal and electrical parameters is systematically created by fouling at the electrode surface because of an increase in the deposit and wall temperatures.

\section{CONCLUSIONS}

The development of alternative (thermal or nonthermal) technologies to pasteurize or sterilize food in a continuous process is of great scientific and industrial interest. Moreover, the fouling of apparatus during pasteurization and sterilization (e.g., of dairy products) remains a severe and recurrent problem in the food industry. Heat treatment by the direct Joule effect exhibits numerous advantages because rapid heating kinetics or homogeneous heat treatment is required. Ohmic heating needs to be investigated with model fluids (under fouling-free conditions) and with real fluids (with fouling). In this work, the thermal, electrical, and hydraulic performance of a continuous ohmic apparatus ( 3 rectangular cells, $e=15 \mathrm{~mm}, w=76 \mathrm{~mm}$, and $L=246 \mathrm{~mm}, \vec{E} \perp \vec{v}$ ) is reported under fouling-free conditions and with fouling caused by whole milk. Fouling at the electrode surface was observed and compared with the conventional type A and B deposits identified in a PHE. In addition, a numerical calculation of temperature profiles (bulk, deposit, and wall) along the ohmic heater was performed for different fouling thicknesses.

The technology investigated shows that several phenomena should be avoided during $\mathrm{OH}$ of fouling liquid food:

- Appearance of mixed convection. Under a laminar flow regimen, a velocity difference between the fluid flowing in the core and the fluid flowing close to the electrode (boundary layer) exists, and the resultant temperature gradient can generate free convection superimposed on the main stream. The results show acceleration of the fluid close to the electrodes, emphasizing the effect of residence time and the mixed convection mechanism (Ould El Moctar et al., 1993; El-Hajal et al., 1998). Consequently, mixed convection increases the heterogeneity of the heat treatment and generates wall overheating along a section. The temperature gradient, $T_{w}-T_{b}$, constitutes a driving force of fouling and should be maintained as low as possible, as opposed to mixed convection.

- A steep temperature gradient between the fluid and electrode, $T_{w}-T_{b}$. Control of the temperature difference is essential because overheating of 
poorly conducting liquids adjacent to hot surfaces not only causes burning or degradation of the liquids, but exacerbates fouling. An empirical correlation was established to estimate the temperature gradient, $T_{w}-T_{b}$, under clean conditions. It defines the operating conditions needed to obtain pure-volume and direct-resistance heating.

- Growth of the fouling deposit. The numerical simulation of working conditions with a deposit demonstrates the difficulty of heating a fouling liquid food by the Joule effect. This analysis highlights a strong interaction between the Joule effect inside the deposit and convective transfer at its surface. Any wall overheating would make the fouling snowball.

- Deviation of the heat dissipation coefficient, $R h_{\mathrm{CO}}$. During the sterilization of whole milk, we observed that the deposit formed inside the ohmic heater appeared similar to classical type A and B fouling in a PHE, although chemical analysis could not be performed. Performance of the ohmic heater remained constant even with a deposit, whereas in a PHE, the heat transfer coefficient decreased and the pressure drop became greater. However, a physical threshold is reached when the heat generated inside the deposit can no longer be evacuated. A drift of the electrical and thermal parameters is then observed $\left(R h_{\mathrm{CO}}\right.$ collapse), which indicates thermal degradation of the deposit (burning due to the Joule effect).

In conclusion, the ohmic heater investigated exhibits a noticeable high conversion ratio from electrical to thermal power. However, its application with fouling liquid food should be restricted 1) to a turbulent flow regimen to avoid mixed convection phenomena and to reduce wall overheating, 2) to heat treatment of fluids with a small propensity to fouling, and 3) to situations in which the deposits formed are thin and have a low electrical conductivity.

\section{REFERENCES}

Alais, C. 1975. Sciences du lait: Principes des techniques laitières. 3rd ed. Ed. Lavoisier Technique \& Documentation, Paris, France.

Amatore, C., M. Berthou, and S. Herbert. 1998. Fundamental Principles of Electrochemical Ohmic Heating of Solutions. J. Electroanalyt. Chem. 457:191-203.

Anderson, A. K., and R. Finkelstein. 1919. A study of the electropure process of treating milk. J. Dairy Sci. 2:374-406.

Aussudre, C., M. Berthou, and P. Terrien. 1998. Présentation des techniques de chauffage des fluides par effet Joule dans l'industrie. Ed. DER-EDF, Moret Sur Loing, France.

Ayadi, M. A. 2005. Traitement thermique des fluides alimentaires encrassants par la technologie de chauffage ohmique en géométrie rectangulaire. Ph.D. Thesis, Université Henri Poincarré, Nancy, France.
Ayadi, M. A., J. C. Leuliet, F. Chopard, M. Berthou, and M. Lebouché. 2004. Continuous ohmic heating unit under whey protein fouling. Innov. Food Sci. Emerg. Technol. 5:465-473.

Berthou, M., and C. Aussudre. 2000. Panorama sur le chauffage ohmique dans l'industrie agro-alimentaire. Ind. Alim. Agric. 7/ 8:31-38.

Berthou, M., M. H. Laurent, and S. Herbert. 1998. Procédé de détermination du comportement electrochimique d'un matériau d'électrode et de mesure de chute de potentiel interfaciale électrodes/ solution dans les conditions de chauffage ohmique, dispositif et applications à cet effet. French Pat. No. 2,776,073.

Bertsch, A. 1981. Propriétés physiques du lait et des crèmes au dessus de $100^{\circ}$ C. Ph.D. Thesis, Ecole Nationale Supérieure des Industries Agricoles et Alimentaires, Massy, France.

Beuf, M., A. Legrand, L. Fillaudeau, J. C. Leuliet, M. Berthou, and P. Terrien. 2001. Critère d'apparition de la convection mixte en régime laminaire dans un échangeur tubulaire à flux de chaleur constant (TPC). Vol. 15. Pages 67-74 in Récent Progrès en Génie des Procédés. A. Strock, J. Boudrant, and D. Tondeur, ed. Ed. Lavoisier Technique \& Documentation, Paris, France.

Bhat, A., and V. K. Joshi. 1998. Ohmic processing of foods: The concept, application, present status and future outlook. Alimentaria (Ennero-Febrero):83-88.

Biss, C. H., S. A. Coombes, and P. J. Skudder. 1989. The development and application of ohmic heating for the continuous heating of particulate food stuffs. Pages 17-25 in Proc. Process Eng. Food Ind. Elsevier, Essex, England.

Brienza, B. M., J. B. Gandy, and L. Lackenback, ed. 1983. Fluid mechanics and heat transfer. In Heat Exchange Design Handbook. Vol. 2. Hemisphere Publ. Corp., Washington, DC.

Burton, H. 1968. Reviews of the progress of dairy science. J. Dairy Res. 35:317-330.

De Alwis, A. A. P., and P. J. Fryer. 1990. The use of direct resistance heating in the food industry. J. Food Eng. 11:3-27.

Delplace, F. 1995. Identification des échangeurs de chaleur à plaques. Application à l'étude de l'encrassement par les produits laitiers. Ph.D. Thesis, Université Henri Poincarré, Nancy, France.

Delplace, F., and J. C. Leuliet. 1995. Modelling fouling of a plate heat exchanger with different flow arrangements by whey protein solutions. Trans. IChemE. 73:112-120.

Delplace, F., J. C. Leuliet, and D. Levieux. 1997. A reaction engineering approach to the analysis of fouling by whey proteins of a six-channels-per-pass plate heat exchanger. J. Food Eng. 34:91-108.

Delplace, F., J. C. Leuliet, and J. P. Tissier. 1994. Fouling experiments of a PHE by whey protein solutions. Trans. IChemE. 72:163-169.

El-Hajal, J. 1997. Etude expérimentale et numérique de la convection mixte dans un écoulement de Poiseuille en présence d'une dissipation volumique d'énergie par conduction électrique directe. Ph.D. Thesis, Institut des Sciences de l'Ingénieur en Thermique, Energétique et Matérieu, Nantes, France.

El-Hajal, J., A. Ould El Moctar, and H. Peerhossaini. 1998. Convection mixte dans un écoulement de Poiseuille vertical: Etude comparative de chauffage volumique et pariétal à flux constant. Int. Comm. Heat Mass Transfer 25:309-319.

Eliot-Godereaux, S., F. Zuber, and A. Goullieux. 2001. Processing and stabilisation of cauliflower by ohmic heating technology. Innov. Food Sci. Emerg. Technol. 2:279-287.

Fillaudeau, L. 2004. Chauffage des fluides agroalimentaires par effet Joule direct: Conductivité électrique et expressions analytiques des profils de température. Ind. Alim. Agric. 26:9-18.

Fillaudeau, L., G. Delaplace, J. C. Leuliet, J. P. Tissier, M. Berthou, and F. Chopard. 2001. Ohmic heating to achieve UHT sterilization of milk-Comparison with plate heat exchanger and definition of a heat dissipation coefficient. Pages 713-718 in ExHFT-5: Experimental Heat Transfer, Fluid Mechanics and Thermodynamics 2001. Vol. 1. G. P. Celata, P. Di Marco, A. Goulas, and A. Mariani, ed. Edizioni ETS, Pisa, Italy.

Fillaudeau, L., V. Maury, and P. Debreyne. 2004. Echangeur de chaleur à effet Joule direct en agroalimentaire: Mesure et modélisation des températures pariétales et du fluide. Pages 135-140 in 
Rencontres AGORAL (Nantes, France), Nov. 30-Dec. 1, 2004. Ed. Lavoisier Technique \& Documentation, Paris, France.

Getchell, B. E. 1935. Electric pasteurization of milk. Agric. Eng. $16: 408-410$

Lalande, M., J. P. Tissier, and G. Corrieu. 1984. Fouling of a plate heat exchanger used in UHT sterilisation of milk. J. Dairy Res. $51: 557-568$

Lyster, R. L. J. 1965. The composition of milk deposit in UHT plant. J. Dairy Res. 32:203-209.

Norrish, R.S. 1967. Scientific and Technical Surveys, Selected Tables of Physical Properties of Sugar Solutions. Leatherhead/British Food Manufacturing Industries Research Association, London, UK.

Ould-El-Moctar, A. 1992. Etude des phénomènes physiques couplés lors du chauffage volumique d'un liquide ionique en écoulement par conduction électrique directe. Ph.D. Thesis, Ecole centrale de Nantes, Nantes, France.

Ould-El-Moctar, A., H. Peerhossaini, P. Le Peurian, and J. P. Bardon. 1993. Ohmic heating of complex fluids. Int. J. Heat Mass Transfer $36: 3143-3152$.

Prescott, S. C. 1927. The treatment of milk by an electrical method. Am. J. Public Health 17:221-223.

Samaranayake, C. P., and S. K. Sastry. 2005. Electrode and pH effects on eletrochemical reactions during ohmic heating. J. Electrochem. Chem. 577:125-135.

Sastry, S. K. 2003. Ohmic heating. Pages 707-711 in Encyclopedia of Agricultural, Food, and Biological Engineering. D. R. Heldman, ed. Marcel Dekker, New York, NY.

Sastry, S. K., and S. Palaniappan. 1992. Mathematical modeling and experimental studies on ohmic heating of liquid-particle mixtures in a static heater. J. Food Process Eng. 15:241-261.

Tissier, J. P., M. Lalande, and G. Corrieu. 1984. A study of milk deposit on heat exchanger surface during UHT treatment. Pages 49-58 in Engineering and Food: Engineering Sciences in the Food Industry. Vol. 1. B. McKenna, ed. Elsevier Applied Science, London, UK.

Weast, R. C., ed. 1983-1984. Handbook of Chemistry and Physics. 64th ed. CRC Press, Inc. Boca Raton, FL.

Yang, T. C. S., J. S. Cohen, R. A. Kluter, P. Tempest, C. Manvell, S. J. Blackmore, and S. Adams. 1997. Microbiological and sensory evaluation of six ohmically heated stew type foods. J. Food Qual. 20:303-313.

Ye, X., R. Ruan, P. Chen, K. Chang, K. Ning, I. A. Taub, and C. Doona. 2003. Accurate and fast temperature mapping during ohmic heating using proton resonance frequency shift MRI thermometry. J. Food Eng. 59:143-150.

Zareifard, M. R., H. S. Ramaswamy, M. Trigui, and M. Marcotte. 2003. Ohmic heating behaviour and electrical conductivity of twophase food system. Innov. Food Sci. Emerg. Technol. 4:45-55.

\section{APPENDIX: NOMENCLATURE}

\section{Latin Letters}

$C \quad$ Specific heat capacity (J/kg per K)

$D P \quad$ Pressure drop $(\mathrm{Pa})$

$e \quad$ Space between plate or electrode $(\mathrm{m})$

$E \quad$ Electrical field $(\mathrm{V} / \mathrm{m})$
EE

$h_{g}$

$g$

I

$L$

$L M$

$m$

$P$

$Q$

$r$

$R e$

$R h$

$R h_{\mathrm{CO}}$

$R T$

$S$

$S P$

$t$

$T$

$U$

$v$

$w$

$x, y$
Energy efficiency (\%)

Overall heat transfer coefficient (W/K per $\mathrm{m}^{2}$ )

Gravity $\left(\mathrm{m} / \mathrm{s}^{2}\right)$

Current (A)

Length of plate (PHE) or electrode (m)

Lipid content (\% wt/wt)

Temperature factor $\left(/{ }^{\circ} \mathrm{C}\right)$

Power (W)

Volume flow rate $\left(\mathrm{m}^{3} / \mathrm{s}\right)$

Electrical resistance $(\Omega)$

Reynolds number (no units)

Reduced heat transfer coefficient (no units)

Heat dissipation coefficient (no units)

Mean residence time ( $\mathrm{s}$ )

Surface area $\left(\mathrm{m}^{2}\right)$

Section $\left(\mathrm{m}^{2}\right)$

Time (s)

Temperature $\left({ }^{\circ} \mathrm{C}\right)$

Electrical potential (V)

Velocity $(\mathrm{m} / \mathrm{s})$

Width of plate or electrode $(\mathrm{m})$

Lengthwise and widthwise position (m)

\section{Greek Letters}

$\begin{array}{ll}\alpha & \text { Slope }\left({ }^{\circ} \mathrm{C} / \mathrm{W}\right) \\ \mu & \text { Viscosity }(\mathrm{Pa} \cdot \mathrm{s}) \\ \lambda & \text { Thermal conductivity }(\mathrm{W} / \mathrm{m} \text { per } \mathrm{K}) \\ \rho & \text { Volume mass }\left(\mathrm{kg} / \mathrm{m}^{3}\right) \\ \sigma & \text { Electrical conductivity }(\mathrm{S} / \mathrm{m}) \\ \Phi_{V} & \text { Viscous dissipation }\left(\mathrm{W} / \mathrm{m}^{3}\right)\end{array}$

\section{Subscripts}

$0 \quad$ Initial condition

$b \quad$ Product (bulk)

$d \quad$ Deposit

e Inlet

elec Electrical

lin Linear

$s \quad$ Outlet

ther Thermal

$w \quad$ Wall 